Agro-Science Journal of Tropical Agriculture, Food, Environment and Extension

Volume 20 Number 4 (Special Issue, October 2021) pp. 22 - 27

ISSN 1119-7455

\title{
EFFECTIVE BIOTECHNOLOGIES FOR REVOLUTIONALIZING THE LIVESTOCK INDUSTRY IN NIGERIA AFTER COVID-19 PANDEMIC
}

\author{
*Ezekwe A.G., Machebe N.S. and Uzochukwu I.E. \\ Department of Animal Science, University of Nigeria, Nsukka, Nigeria \\ *Corresponding author's email: arinze.ezekwe@unn.edu.ng
}

\begin{abstract}
COVID-19 pandemic has caused severe health and hunger challenges both in developed and developing economies of the world thereby posing a serious threat to the economies and food security issues particularly of vulnerable regions of the world. Currently in Nigeria, there is a great increase in the market prices of crops and livestock products occasioned by the prevailing clashes between crop farmer and livestock herders. There is thus a huge gap in the demand and supply of available essential agricultural products leading to the high inflation rate being witnessed in the country today. With the current population of over 200 million which is expected to double by 2050, the task of feeding these Nigerians is daunting and very challenging. To overcome these challenges, the livestock industry in Nigeria needs to be transformed accordingly. FAO report of 2019 had advised African livestock producers to work to expand the scope of their operations and to invest in productivity-enhancing technologies in order to meet the growing demands for livestock products. The adoption of biotechnological innovations already available in animal reproduction, nutrition, health and genetics, is a clear pathway to enhance livestock production in Nigeria. The Nigerian Government is expected to play a leading role by providing enabling environment that will make for easy and seamless adoption of these technologies. Nigerian livestock farmers on their part should be ready and willing to embrace these technologies to enhance the productive capacity of their stock as well as improving their own welfare and economic wellbeing.
\end{abstract}

Key words: COVID-19 pandemic, biotechnology, livestock industry, development, Nigeria

\section{INTRODUCTION}

Food insecurity is a major challenge in many developing countries including Nigeria. FAO et al. (2020) reported that about $12.6 \%$ of Nigerians were under-nourished between 2017 and 2019. This situation has worsened due to the steady rise in human population coupled with the current state of insecurity pervading in the country which has negatively affected food production, distribution and accessibility in Nigeria. The resultant effect is the galloping food prices being witnessed in the country today. Nigeria's population is growing at the rate of about $3.5 \%$ per annum and with the current population of ca. 200 million, it is projected that by 2050, Nigeria's population will double to about 400 million (FAO et al., 2020). It is also projected that the number of people living in urban areas will triple from the current 94 million to 280 million. As a consequence of this demographic change, the demand for livestock products will rise exponentially and the projection is that poultry meat, beef and milk consumption will grow by $253 \%, 117 \%$ and $577 \%$, respectively, by 2050 (FAO et al., 2018).

The recent incidence of COVID-19 pandemic has caused severe health and hunger challenges particularly, in low- and middle-income countries like Nigeria, that are considered most susceptible regions. Public health safety measures instituted to manage the spread of this disease included social distancing, schools and market closures, banning of social events, airports and boarder closures, total lockdown (in most affected areas), and restrictions on inter-state persons and vehicular movements (Ilesanmi et al., 2020; Ilesanmi and Afolabi, 2021). Consequently, these measures have resulted in a substantial impact on sectors of Nigerian economy including the livestock industry. Its negative impact on livestock production was felt through reduced access to feeds, inputs, and services, markets, and consumers. In the area of processing, the capacity of the industry for animal product processing, storage, and conservation was seriously affected.

Additionally, the nation's capacity for animal health testing and diagnostics, as well as disease surveillance and reporting were disrupted (Fafiolu and Alabi, 2020). A recent report by a World Bank group in May, 2020 predicted a further deterioration of the food insecurity challenges especially in the poor and vulnerable regions following the COVID-19 pandemic (FAO, 2019). This is already evident in the current hike in the market prices of crop and livestock products which are grossly in short supply, with attendant steady rise in inflation across the country. In order to respond to these increasing demands, the livestock industry will need to be transformed accordingly.

Please cite as: Ezekwe A.G., Machebe N.S. and Uzochukwu I.E. (2021). Effective biotechnologies for revolutionalizing the livestock industry in Nigeria after COVID-19 pandemic. Agro-Science, 20 (4, Special Issue), 22-27. DOI: https://dx.doi.org/10.4314/as.v20i4.3 
Meeting the increased demand for animal products will require rapid growth in herd size and increased productivity of existing herds arising from some level of intensification in the production systems. Report by FAO (2019) had advised African livestock producers to work to expand the number of their livestock and also to invest in productivity enhancing technologies if they are to meet the increasing demands for livestock products.

Biotechnology has the potential to improve the productivity of animals via increase in growth, carcass quality, efficient reproduction, improved nutrition and feed utilization, improved quality and safety of food, improved health and welfare of animals and reduced waste through more efficient utilization of resources (Tonamo, 2015). The rising demand for animal products coupled with the expected transformation of the sector will create great opportunities for livestock farmers to expand their businesses into such areas as input suppliers, animal health, service providers, processors, wholesalers, and retailers, etc. These business opportunities are expected to stimulate and promote socio-economic activities in the country through wealth creation and sustainable food security.

The national livestock populations as at 2017 were reported as 18.4 million cattle, 43.4 million sheep, 76 million goats, and 180 million poultry (FMARD, 2017); with the majority of the livestock kept/reared under extensive husbandry systems, comprising small holders and nomadic herders. Large commercial livestock farms are few in number except in the poultry subsector where medium to large scale commercial operations abound. The National Livestock Transformation Plan (NLTP) 2019-2028 was therefore launched by the Nigeria government to ensure that the livestock sector becomes a catalyst for building national prosperity. The plan proposes strategic interventions to support improved performance and sustainability of livestock enterprises in Nigeria. One of the objectives of the plan is to establish ranches to take care of migratory herders whose activities have been the major cause of conflict with crop farmers all over the country.

Full implementation of the NLTP is expected to open up the livestock industry in Nigeria to market oriented corporate and individual players who will be ready to embrace technological innovations available in the industry to enhance their operations and optimize their profit. This review is intended to highlight those biotechnological innovations that need to be embraced by livestock farmers in Nigeria to improve their production efficiency, increase the productivity of their stock, and ultimately make meat and animal products readily available to Nigerians.

Biotechnologies for Livestock Production in Nigeria Biotechnology is the application of biological principles in manipulating living organisms or their derivatives in order to improve or multiply a product (Kahl and Rewe, 2008). It is increasingly becoming a sustainable means of improving livestock production globally. Biotechnologies in animal agriculture can be categorized as the biological, chemical, and physical techniques that influence animal health, nutrition, breeding, and reproduction (Bonneau and Laarveld, 1999). There are several biotechnological innovations that can be applied in different facets of animal production in Nigeria to enhance the productivity of local herds/flocks.

\section{Biotechnologies in Animal Reproduction Artificial insemination}

The traditional method used in animal reproduction is natural mating. However, artificial insemination (AI) is the most popular method that has been widely adopted in livestock industries in developed countries and to a less extent in the developing world. The AI is by far the most widely used biotechnology in animal reproduction. The use of AI in animal reproduction has been reported to result in genetic progress that is four times better than natural mating (Van Vieck, 1981; Negussie, 2011).

The AI is the procedure that involves the mechanical deposition of semen from superior sires (males) in the uterus of an estrus female by a technician for the purpose of conception (Alexander et al., 2010). It is the most widely used biotechnology in animal reproduction both in developed and developing world. According to FAO (2006), about 100 million cattle, 40 million pigs, 3.3 million sheep, and 0.5 million goats are bred annually by AI globally. The AI is recognized as the best biotechnology technique for increasing reproductive capacity of farm livestock. The widescale adoption and application of this technology in dairy cattle, pig, and poultry has dramatically revolutionized the industry mainly due to well established methods of identifying males with high genetic traits (Baldassarre and Karatzas, 2004).

The AI has many advantages such as reducing the spread of venereal diseases, rapidly increasing genetic merits of animals through selective breeding, elimination of lethal genes from animal herds, insemination of many females with semen from one male (Alexander et al., 2010). The AI also offers a low-cost approach and relatively simple method for dissemination of valuable genes.

The livestock industry in Nigeria will benefit immensely from this technology if farmers will be willing to adopt improved management systems instead of the current practice of pastoralism and transhumance, which is not compatible with the practice of artificial insemination as a globally recognized tool for rapid genetic transformation of local livestock populations. In Nigeria, the largely extensive system of animal husbandry, the lack of necessary infrastructure, absence of national data base for animal registration and identification, absence of national breeding policy, coupled with shortage of trained AI personnel constitute a major obstacle to the successful adoption of AI programme. 


\section{Oestrus synchronization}

The ability of livestock producers to satisfy the increasing demands for livestock products depends largely on their capacity to enhance production efficiency as well as the productivity of farm livestock. Among the options available to small holder livestock producers in Nigeria to increase the productivity of their stock is to adopt time tested and workable technologies which have transformed the livestock industry in developed countries.

One of such options is oestrus synchronization of breeding female stock. It is a procedure that makes a number of breeding females to come into estrus at about the same time. According to Baldassarre and Karatzas (2004), this procedure is a key component of all the modern reproductive technologies practiced in livestock production as it influences the overall efficiencies of other programmes.

Oestrus synchronization methods are used mainly for the artificial replacement of the corpus luteum in cattle, sheep and goats using progesterone releasing intravaginal device, intravaginal progesterone sponges, progesterone ear implant or prostaglandin (PGF2 $\alpha$ ) treatment. Also, hormones such as pregnant mare serum gonadotropin (PMSG) and human chorionic gonadotropin (hCG) have been used to induce estrus in lactating sows (Britt et al., 1985). Withdrawal of devices from treated animals will result in synchronous estrus in such individuals. These hormones when administered appropriately either as single dose or in combination, depending on the species are used to control the luteal phase of the cycle of breeding females either by extending or terminating the luteal phase of the oestrus cycle (Shelton, 1990; Perera, 1999). This procedure makes large scale artificial insemination of breeding females possible over a short period.

\section{Multiple ovulation and embryo transfer}

Multiple ovulation or super ovulation is a procedure whereby elite females are treated with gonadotropin to induce multiple ovulations. Embryo donor is then inseminated with semen from genetically superior males. Thereafter, embryos are collected from embryo donors by surgical (as in sheep and goats) or non-surgical (as in cattle) procedures. These genetically superior embryos are then evaluated for quality before being transferred to genetically inferior but fertile females. Depending on the species, the transfer can be carried out through surgical or nonsurgical technique. Embryo transfer enables birth of multiple progeny from genetically superior females. In cattle, up to 5-6 good quality embryos can be collected after each superovulation and $50-60 \%$ of recipients generally conceive following embryo transfer. In the United States and Canada about $80 \%$ of breeding are carried out using this technology. Table 1 presents the number of sheep and goat embryos transferred globally in 2008 .
Multiple ovulation and embryo transfer (MOET) increases the scope to select females whereas AI limits selection to males (FAO, 2011). FAO (2007) report showed that in Africa, only Cote d'Ivoire, Kenya, Madagascar, Zambia and Zimbabwe use embryo transfer technology but on a very limited scale. This report clearly indicates that this technology is practicable in developing countries where the required institutional framework, infrastructure and human capacity are available.

\section{Pregnancy diagnosis}

One of the numerous challenges facing the Nigeria's livestock industry is the high incidence of foetal wastage. On daily basis across the country, fetuses at different stages of development are being lost in the abattoirs. Unfortunately, most of these foetal losses are avoidable but for the system of livestock production being practiced by majority of livestock farmers in Nigeria. A production system that allows uncontrolled mating of animals with no records of such mating; it becomes extremely difficult for farmers to identify which animals were mated when and by which male. Data from abattoir studies in Nigeria revealed that between $10-30 \%$ of female animals (cattle, sheep, goats and pigs) slaughtered annually are pregnant (Oyekunle et al., 1992; Ayodele et al., 2003). For a country that spends billions of naira annually importing meat and animal products, such wastages are unacceptable. Routine pregnancy diagnosis at the farm level will greatly reduce the number of pregnant animals that are offered for sale thereby drastically reducing the number of fetuses that are inadvertently wasted in slaughter houses across the country.

Pregnancy diagnosis using transrectal ultrasonography can reliably diagnose pregnancy from 30 days of gestation (Goncu and Gungor, 2018). Enzyme Linked Immunosorbent Assay (ELISA), radioimmunoassay (RIA) or latex agglutination tests carried out on either the blood or milk samples of females can also be used to test for pregnancy. Again, detection of estrone sulfate, progesterone and glycoproteins can equally be used as indicators of pregnancy in cattle (Whitlock and Maxwell, 2008; Athanasios et al., 2010).

\section{Biotechnologies in Animal Nutrition}

The productivity of an animal depends on its genetic make-up and the environment. The major components of the environment include; nutrition, housing, disease etc. High cost and poor quality of available feed resources represent major constraints to livestock production in sub-Sahara Africa.

Table 1: World embryo transfer activity in small ruminants

\begin{tabular}{llccc}
\hline \multirow{2}{*}{ Species } & Transferable & \multicolumn{3}{c}{ Transferred embryos } \\
\cline { 3 - 5 } & embryos & Fresh & Frozen & Total \\
\hline Sheep & 18828 & 4793 & 433 & 5226 \\
Goat & 3141 & 824 & 278 & 1102 \\
\hline
\end{tabular}

Source: Alexander et al. (2010) 
In the tropics, available forages for livestock grazing are predominantly $\mathrm{C} 4$ grasses which are characterized by low energy and protein contents (National Research Council, 2009). Van Soest (1994) analyzed 80 tropical forage materials and observed that $30 \%$ of the forages were deficient in both protein and energy contents, with only about $45 \%$ meeting the maintenance requirements of animals. Again, the high tannin content of many tropical leguminous forages has been observed by Mueller-Harvey (2006) to lower feed intake, dry matter digestibility, inhibit microbial enzyme secretion with the resultant reduction in live weight and milk production. Although ruminants may have access to enough forages during the rainy season, it become a major challenge to effectively feed the animals during the dry season (Lawal-Adebowale, 2012). At this period, most of the forage species have lignified extensively with a great reduction in quality.

In order to resolve these issues associated with livestock feeding and nutrition, and coupled with the recent global interest in food safety issues, animal nutritionists have developed a number of biological products from biotechnological processes. These products are known to enhance the digestibility and utilization of poor-quality feedstuff thereby, increasing the efficiency and profitability of livestock production. Such products include:

\section{i. Enzymes}

Enzymes are proteinaceous biocatalysts, generally of microbial origin that improve nutrients availability by enhancing the digestibility of macromolecules and decreasing the antinutritional factors (FAO, 2010). Exogenous enzymes have been used in the feeds of both monogastrics and ruminants with the aim of increasing their productivity through efficient nutrient utilization. The application of enzymes in poultry nutrition is not a new practice in the industry although it is yet to be optimally adopted by rural farmers in many developing countries including Nigeria. As reported by Plumstead (2014), the results of over 2,500 independent tests showed that feed enzymes such as phytase, xylanase, amylase, and protease can be used to enhance the productivity and profitability of broiler productions. According to this author, optimized combinations of xylanase, amylase, and protease can minimize nutrient variability and viscosity in animal feeds containing wheat, sorghum and protein sources of poor quality resulting in improved digestibility and performance.

In the case of ruminants, the major categories of enzymes used include the fibrolytic (including the cellulase and cellobiose), amylolytic and proteolytic enzymes, with phytase becoming increasingly important in the industry. Many studies have documented significant improvements in fiber digestibility and feed utilizations following administration of exoge-nous enzymes to ruminants in vitro (Rodrigues et al., 2008; Murad et al., 2009; Azzaz, 2009), in vivo (Jalilvand et al., 2008;
Krueger et al., 2008; Arriola et al., 2011), and in situ (Bhasker et al., 2013; Sujani and Seresinhe, 2015). In order to improve the performance and uniformity of their flocks, the use of these enzymes is recommended to Nigerian livestock and poultry farmers. This will go a long way to improve the productivity of the local herds/flocks while reducing the country's dependence on imported products.

\section{ii. Probiotics and Prebiotics}

Probiotics are live microorganisms which when administered in adequate amounts may confer health and production benefits to the host. These probiotics are usually derived from Lactobacillus and Bifidobacterium families for monogastric animals while Aspergillus oryzae and Saccharomyces cerevisiae are used for ruminants (Dabiri et al., 2006; Bahari, 2017). The inclusion of probiotics in feeds is designed to stimulate the proliferation of certain beneficial microbial strains in the gut at the expense of less desirable ones. Therefore, probiotics is seen to serve as a suitable alternative to antibiotics use in animal production. The use of probiotics in healthy animals has been observed to promote nonspecific immune response with a general improvement in livestock productivity (Tona, 2018).

Several studies have shown that supplementation of different probiotics products in the diet of poultry birds significantly increased nutrient digestibility and utilization, and growth in broilers (Zhang et al., 2005; Udeh et al., 2019; Osita et al., 2020). On the other hand, the supplementation of yeasts in ruminant diets has been reported to improve feed intake and digestion (Jouany et al., 1998; Robinson and Garrett, 1999), nutrient absorption, milk production, weight gain and general health of animals (Salama et al., 2002; Osita et al., 2018).

Prebiotics on the other hand are non-digestible food ingredients that beneficially affect the host by selectively stimulating the growth and activity of specific microbial flora in the colon. Alonge et al. (2017) reported an improved broiler performance when mannan oligosaccharide (a prebiotics) was supplemented in the diet of broiler birds.

\section{iii. Silage Additives}

Silage is a green fodder that is conserved through fermentation process. Its nutritional quality depends among other things on the forage materials used and the success of the fermentation process. Microbial inoculants, enzymes and sugars have been developed for addition into the silage during ensiling to stimulate the fermentation process. Additionally, inhibitors such as propionates, nonprotein nitrogen and certain acids may also be incorporated into silage-making to slow down unwanted silage degradation by reducing mould growth or to reduce the breakdown of plant proteins. Lawal-Adebowale (2012) reported that indigenous cattle breeds could gain an average of 0.9-1.2 kg per day when fed silage and concentrate rations. This indicates that local cattle breed has the potentials for efficient utilization of conserved forages. 


\section{Biotechnologies in Animal Health}

Animal health is perhaps one of the most important aspects of animal production and any biotechnological interventions in this area will greatly benefit the industry. Biotechnologies in animal health have been developed in a number of areas to include disease prevention, diagnosis, treatment and control (Bonneau and Laarveld, 1999).

\section{Vaccines}

Disease prevention is probably one of the most important areas in animal health technologies that has resulted in the development of vaccine. Although there are other methods of disease prevention and control, vaccination remains comparatively a sustainable and cheaper means of achieving a healthy stock. Vaccines that are widely used are either attenuated or inactivated and these have been effective in establishing resistance in farm animals. Yilma et al. (2003) had reported that genetic technologies can be used to develop more efficient and effective vaccines to take care of specific disease conditions. Thus, recombinant vaccines are now more preferable than the conventional one due to the zero risk of reversal to its virulent form. Many livestock and poultry disease can now be effectively controlled through appropriate programme of vaccination.

\section{Diagnosis of Disease}

Before the advent of recombinant DNA technologies, the diagnosis and immunological prevention of infectious diseases of animals was based on the use of whole pathogens or their physically resolved fractions. But these methods were largely ineffective.

Many Enzyme Immunosorbent Assay (ELISA) systems now use recombinant antigens for detection of antibodies and produce results with higher sensitivity, specificity, safety and generally more acceptable. Besides, great strides have been made in disease diagnosis using Polymerase Chain Reaction (PCR) technology. These technologies (ELISA and PCR) have played significant roles in the development of many diagnostic kits for accurate detection of animal diseases thereby making the control and treatment of many animal diseases more effective.

\section{CONCLUSION}

The fact that the livestock industry in Nigeria as presently constituted cannot adequately satisfy the growing demand of ever-increasing population is not in doubt. Unless and until livestock farmers in Nigeria begin to apply biotechnological approaches in their production systems, the challenge of achieving sustainable meat and animal products supply to the teeming Nigerian population will persist. The adoption of some of the advances in animal production biotechnologies highlighted in this review will greatly improve livestock productivity and food security in Nigeria as well as enhancing the overall wellbeing of the farmers. Aware of the fact that tremendous achievements in the livestock industries in developed countries through the use of these technologies have been recorded over the years; this should serve to encourage Nigerian livestock farmers to embrace such innovations. However, it is expected that the adoption of these innovative technologies should be gradual as government provides the necessary infrastructural, institutional, and human capacities needed to facilitate and drive the adoption process.

\section{REFERENCES}

Alexander B., Mastromonaco G. and AllanKing W. (2010). Recent advances in reproductive biotechnologies in sheep and goats. J. Vet. Sci. Technol., 1, 1-8

Alonge E., Eruvbetine D., Idowu O. et al. (2017). Effects of antibiotics, probiotics, and prebiotics supplementation in broiler diets on performance characteristics and apparent nutrient digestibility. $J$. Appl. Sci. Environ. Manag., 21 (7), 1297-1300

Arriola K., Kim S., Staples C. and Adesogan A. (2011). Effect of fibrolytic enzyme application to low- and high-concentrate diets on the performance of lactating dairy cattle. J. Dairy Sci., 94, 832-841

Athanasios S., Charalampos Z., Alexander B., Vasileios A. and Eftychia M. (2010). Complete farm management system based on animal identification using RFID technology. Comput. Electron. Agric., 70 (2), 380-388. DOI: 10.1016/j.compag.2009.07.009

Ayodele A., Fadiyimu A., Polikunso A. and Olowu O. (2003). Foetal wastage through the slaughtering of pregnant cows at Akure abattoirs. Proc. $28^{\text {th }}$ Ann. Conf. Nig. Soc. Anim. Prod. (pp. 49-50), 16-20 Mar.

Azzaz H. (2009). Effect of Cellulytic Enzymes Addition to Diets on the Productive Performance of Lactating Goats. MSc Thesis, Faculty of Agric., Cairo Univ., Egypt

Bahari M. (2017). Review on the consumption of probiotics in feeding young ruminants. Appr. Poult. Dairy Vet. Sci., 1 (2). APDV000508

Baldassarre H. and Karatzas C.N. (2004). Advanced assisted reproduction technologies in goat. Anim. Reprod. Sci., 53, 255-266

Bhasker T., Nagalakshmi D. and Rao D. (2013). Development of appropriate fibrolytic enzyme combination for maize stover and its effect on rumen fermentation in sheep. Asian-Austral. J. Anim. Sci., 26, 945-951

Bonneau M. and Laarveld B. (1999). Biotechnology in animal nutrition, physiology and health. Livest. Prod. Sci., 59, 223-241

Britt J.H., Armstrong J.D., Cox N.M. and Esbenshade K.L. (1985). Control of follicular development during and after lactation in sows. In: Control of Reproduction II (pp. 37-54). Proc. 2nd Int. Symp. on Pig Reproduction, Columbia, MO

Dabiri N., Hajimohammadi A., Mahdavi A. et al. (2006). Effect of different levels of biosaf probiotic in medium concentrate diet on performance and blood factors of Iranian Zandi lambs. J. Fish. Livest. Prod., 4 (4), 1-4

Fafiolu A. and Alabi J. (2020). Beyond COVID-19 pandemic period: Strategies for sustainable livestock feed and food production. Nig. J. Anim. Sci., 22 (3), 107-121

FAO (2006). The state of development of biotechnologies as they relate to the management of animal genetic resources and their potential application in developing countries. Commission on Genetic Resources for Food and Agriculture Organization (FAO) of the United Nations, Background Study Paper 33, Rome

FAO (2007). The state of the world's animal genetic resources for food and agriculture. In: Rischkowsky, B. and Pilling D. (eds.). Chapter $3 \mathrm{~d}$ 
FAO (2010). Poultry feed availability and nutrition in developing countries. In: Ravindran V. (ed.), Poultry Development Review. FAO of the United Nations, Rome

FAO (2011). Biotechnologies for agricultural development. In: Agricultural Biotechnologies in Developing Countries: Options and Opportunities in Crop, Forestry, Livestock, Fisheries and Agro-Industry to Face the Challenges of Food Insecurity and Climate Change (ABDC-10), Proc. FAO Int. Conf., GDL Mexico, 1-4 Mar

FAO (2019). The future of livestock in Nigeria. In: Opportunities and Challenges in the Face of Uncertainty: Guidelines. FAO, Rome

FAO, IFAD, UNICEF, WFP and WHO (2018). The State of Food Security and Nutrition in the World 2018: Building climate resilience for food security and nutrition.FAO,Rome. http://www.fao.org/3/i9553en/i9553en.pdf

FMARD (2017). Animal population data. Federal Ministry of Agriculture and Rural Development, Nigeria

Goncu S. and Gungor C. (2018). The innovative technologies in animal husbandry. In Yucel B. and Taskin T. (eds.), Animal Husbandry and Nutrition (pp. 4-21). Intechopen. DOI: 10.5772/intechopen.72501

Ilesanmi O.S and Afolabi A.A. (2021). COVID-19 waves in Africa: Effects of outbreak response and interventions. Glob. Biosecur., 3 (1). DOI: 10.31646/gbio.104

Ilesanmi O., Olabumuyi O. and Afolabi A. (2020). Mobilizing medical students for improved COVID-19 response in Nigeria: A stop gap in human resources for health. Glob. Biosecur., 2 (1). DOI: 10.31646/gbio. 89

Jalilvand G., Naserian A., Kebreab E. et al. (2008). Rumen degradation kinetics of alfalfa hay, maize silage and wheat straw treated with fibrolytic enzymes. Arch. Zootec., 57, 155-164

Jouany J., Mathieu F., Senaud J. et al. (1998). The effect of Saccharomyces cerevisiae and Aspergillus oryzae on the digestion of the cell wall fraction of a mixed diet in defaunated and refaunated sheep rumen. Reprod. Nutr. Dev., 38, 401-416

Kahl A. and Rewe T. (2008). Biotechnology in livestock Production: Overview of possibilities for Africa. Afr. J. Biotechnol., 7, 4984-4991

Krueger N., Adesogan A., Staples C. et al. (2008). Effect of method of applying fibrolytic enzymes or ammonia to Bermuda grass hay on feed intake, digestion and growth of beef steers. J. Anim. Sci., 86, 882-889

Lawal-Adebowale O.A. (2012). Dynamics of ruminant livestock management in the context of Nigerian agricultural system. Livest. Prod., 4, 1-20

Mueller-Harvey I. (2006). Review unravelling the conundrum of tannins in animal nutrition and health. J. Sci. Food Agric., 86, 2010-2037

Murad H., Hanfy M., Kholif A., Abdel-Gawad M. and Murad H. (2009). Effect of cellulases supplementation to some low-quality roughages on digestion and milk production by lactating goats. J. Biol. Chem. Environ. Sci., 4, 791-809

National Research Council (2009). Emerging Technologies to Benefit Farmers in sub-Saharan Africa and South Asia. Washington DC: The National Academies Press. https://doi.org/10.17226/12455

Negussie E. (2011). Livestock and livelihoods: Role of advances in animal breeding and biotechnology. Horn Afr. J. Online at https://afrikansarvi.fi/issue1/ 15-artikkeli/31-livestock-and-livelihoods-role-ofadvances-in-animal-breeding-and-biotechnology

Osita C., Ani A., Ezema C. et al. (2018). Hematological and biochemical indices of West African Dwarf sheep fed diets containing yeast (Saccharomyces cerevisiae), grass, grass/legume (50:50) and legume. Pak. J. Nutr., 18, 34-41
Osita C., Ani A., Oyeagu C. et al. (2020). Effect of different levels of dietary inclusion of Saccharomyces cerevisiae on growth performance and hematological parameters in broiler birds. Bulg. J. Agric. Sci., 26 (5), 1024-1028

Oyekunle M., Olubanjo O. and Fasina O. (1992). Foetal wastage in abattoirs and its implications: Situation report from Ogun State, Nigeria. Nig. J. of Anim. Prod., 19, 57-63

Perera A. (1999). Management of reproduction. In: Falvey L. and Chantalakhan. (eds.), Smallholder Dairy in the Tropics. ILRI-Kenya

Plumstead P. (2014). Feed enzymes can grow Nigerian poultry producers' profitability. Wattagnet.com. WATTPoultry.com. 21 Sep., 2014

Robinson P. and Garrett J. (1999). Effect of yeast culture (Saccharomyces cerevisiae) on adaptation of cows to postpartum diets and on lactational performance. $J$. Anim. Sci., 77, 988-999

Rodriguez M., Pinto R., Bezerra M. et al. (2008). Effect of enzyme extracts isolated from white-rot fungi on chemical composition and in vitro digestibility of wheat straw. Anim. Feed Sci. Technol., 141, 326-338

Salama A.A.K., Garin G., Albanell E., Sush X. and Casais R. (2002). Effects of adding a mixture of malate and yeast culture (Saccharomyces cerevisiae) on milk production of murciano-granadina dairy goats. Anim. Res., 51, 295-303

Shelton J.N. (1990). Reproductive technology in animal production. Rev. Sci. Tech. (Off Int. Epiz.), 9 (3), 825-845. DOI: http://dx.doi.org/10.20506/rst.9.3.521

Sujani S. and Seresinhe R. (2015). Exogenous enzymes in ruminant nutrition: A review. Asian J. Anim. Sci., $9(3), 85-99$

Tonamo A. (2015). Review of current status of animal biotechnology and options for improving animal production in developing countries. Adv. Life Sci. Tech., 38, 29-39

Tona G. (2018). Current and future improvements in livestock nutrition and feed resources. Anim. Husb. Nutr. DOI: 10.5772/intechopen.73088

Udeh F., Ilo S., Udeh V. and Ugwu C. (2019). Growth performance and hematological profile of broiler chickens served dietary inclusion of probiotics (Saccharomyces cerevisiae) and enzyme (bioenzyme). Nig. J. Anim. Prod., 46 (5), 143-148

Van Soest P. (1994). Fiber and physicochemical properties of feeds. In: Van Soest P. (ed.), Nutritional Ecology of the Ruminant (2 $2^{\text {nd }}$ edn.; pp. 140-155). Cornell University Press, Ithaca and London

Van Vieck L. (1981). Potential genetic impact of artificial insemination, sex selection, embryo transfer, cloning and sexing in dairy cattle. In: Bracket B., Siedel E. and Siedel S. (eds.), New Technologies in Animal Breeding (pp. 221-242). Academic Press, NY

Whitlock B. and Maxwell H. (2008). Pregnancyassociated glycoproteins and pregnancy wastage in cattle. Theriogenology, 70, 550-559. DOI: 10.1016/j.theriogenology.2008.05.003

Yilma T., Ahmad S., Jones L. et al. (2003). Inexpensive vaccines and rapid diagnostic kits tailor-made for the global eradication of rinderpest. In: Brown F. and Roth J. (eds.), Vaccines for OIE List A and Emerging Animal Diseases (pp. 99-111). Proc. Int. Symp. Ames, Iowa, 16-18 Sep., Basle, Karger Switzerland

Zhang A., Lee B., Lee K. et al. (2005). Effects of yeast (Saccharomyces cerevisiae) cell components on growth performance, meat quality, and ileal mucosa development of broiler chicks. Poult. Sci., 84 (7), 1015-1021 